Prawo Budżetowe Państwa i Samorządu

ISSN 2300-9853
$4[4] / 2016$

DOI: http://dx.doi.org/10.12775/PBPS.2016.022

\title{
Modele realizacji zadań własnych gminy na gruncie ustaw: o zbiorowym zaopatrzeniu w wodę i zbiorowym odprowadzaniu ścieków, o publicznym transporcie zbiorowym i o utrzymaniu czystości i porządku w gminach
}

Models tasks of the municipality on the basis of laws: the collective water supply and discharge of wastewater, the public transport and on maintaining cleanliness and order in municipalities

Streszczenie. Gminy realizują liczne zadania własne. W tym celu mogą tworzyć własne jednostki organizacyjne, a także zawierać umowy z przedsiębiorcami prywatnymi. Zasady wykonywania różnych zadań własnych określają ustawy szczególne, z których wynika, w jaki sposób gmina może te zadania realizować. Na gruncie ustaw szczególnych można wskazać na pewne modele postępowania, np. obowiązek zawierania umów cywilnoprawnych, możliwość tworzenia własnych podmiotów czy rozwiązania mieszane. Przedmiotem artykułu jest próba 
analizy modeli działania gminy na gruncie ustaw: o zbiorowym zaopatrzeniu w wodę i zbiorowym odprowadzaniu ścieków, o publicznym transporcie zbiorowym oraz o utrzymaniu czystości i porządku w gminach.

Słowa kluczowe: zadania własne gminy; zbiorowe zaopatrzenie w wodę i zbiorowe odprowadzanie ścieków; publiczny transport zbiorowy; utrzymanie czystości i porządku w gminach.

Abstract. The municipalities carry out numerous tasks of their own. For this purpose, they can create their own organizational units, as well as enter into contracts with private entrepreneurs. The rules of the various tasks are defined by the specific laws, which shows how the municipality can carry out these tasks. On the basis of special laws there are some models of conduct, eg. an obligation to conclude a civil law contract, to create their own entities or mixed solutions. The article attempts to analyze the models of carry out the municipalities own tasks on the basis of laws: the collective water supply and discharge of wastewater, the public transport and on maintaining cleanliness and order in municipalities.

Keywords: municipality own tasks; collective water supply and collective discharge of wastewater; public transport; maintaining cleanliness and order in municipalities.

\section{Uwagi wstępne. Cel i przedmiot opracowania}

Gmina została ukształtowana jako podstawowa jednostka samorządu terytorialnego. Realizuje ona liczne zadania, wśród których najważniejszymi są zadania własne. Znaczenie tych zadań wiąże się z tym, że są one związane z zaspokojeniem zbiorowych potrzeb mieszkańców tej wspólnoty samorządowej. Gmina ma obowiązek realizowania ich ${ }^{1}$.

Gmina może realizować zadania własne w różnych formach prawnych, np. zakładów budżetowych czy spółek prawa handlowego, oraz w różny sposób, np. zawierając umowy z podmiotami zewnętrznymi czy powierzając wykonanie zadania własnym jednostkom organizacyjnym lub

\footnotetext{
A. Borodo, Samorzq̨ terytorialny. System prawnofinansowy, Warszawa 2008, s. 37-38; H. Izdebski, Samorzq̨d terytorialny. Podstawy ustroju i działalności, Warszawa 2009, s. 133-134.
} 
osobom prawnym. Dopuszczalne formy i sposoby realizacji zadania własnego zależą od rodzaju danego zadania i innych okoliczności. Zgodnie z ogólną zasadą wyrażoną w ustawach o samorządzie gminnym oraz o gospodarce komunalnej ${ }^{2}$ gmina sama decyduje o tym, w jakiej formie i w jaki sposób będzie realizowała dane zadanie. Ta zasada jest jednak istotnie ograniczana z uwagi na istnienie ustaw szczególnych, które mogą narzucać gminie określony sposób realizacji danego zadania, np. nakazując stosowanie ustawy Prawo zamówień publicznych ${ }^{3}$ lub innych ustaw.

Pojęcie zadań własnych jest zdefiniowane w art. 166 ust. 1 Konstytucji $\mathrm{RP}^{4}$ jako zadania publiczne służące zaspokajaniu potrzeb wspólnoty samorządowej. Ustawa o samorządzie gminnym w art. 7 ust. 1 stanowi, że do zadań własnych gminy należy zaspokajanie zbiorowych potrzeb wspólnoty. Z pojęciem zadań własnych ściśle wiąże się pojęcie zadań o charakterze użyteczności publicznej oraz pojęcie gospodarki komunalnej. Zgodnie z art. 1 ust. 2 u.g.kom. gospodarka komunalna obejmuje w szczególności zadania o charakterze użyteczności publicznej, których celem jest bieżące i nieprzerwane zaspokajanie zbiorowych potrzeb ludności w drodze świadczenia usług powszechnie dostępnych. Z przytoczonej definicji wynika, że cechą zadań własnych realizowanych przez gminę jest zaspokajanie zbiorowych potrzeb wspólnoty samorządowej, a sposobem realizacji tych zadań jest świadczenie usług powszechnie dostępnych $^{5}$. Poprzez zbiorowe potrzeby wspólnoty rozumie się potrzeby, które są odczuwane przez ogół, zbiorowość mieszkańców. Są to potrzeby elementarne, podstawowe, których zaspokojenie jest niezbędne. Natomiast usługi powszechnie dostępne to usługi, które są dostępne dla wszystkich, mające charakter niewykluczalny ${ }^{6}$. Z przytoczonych przepisów wynika,

2 Por. art. 3 ust. 1 ustawy z dnia 20 grudnia 1996 r. o gospodarce komunalnej (tekst jedn. Dz.U. z 2016 r., poz. 573, dalej: u.g.kom.) oraz art. 9 ust. 1 ustawy z dnia 8 marca 1990 r. o samorządzie gminnym (tekst jedn. Dz.U. z 2016 r., poz. 446, dalej: u.s.g.).

3 Ustawa z dnia 29 stycznia 2004 r. (tekst jedn. Dz.U. z 2015 r., poz. 2164 ze zm., dalej: P.z.p.).

4 Konstytucja RP z dnia 2 kwietnia 1997 r. (Dz.U. z 1997 r. Nr 78, poz. 483 ze zm.).

5 Art. 9 ust. 4 u.s.g. definiuje zadania użyteczności publicznej jako zadania własne gminy, określone w art. 7 ust. 1, których celem jest bieżące i nieprzerwane zaspokajanie zbiorowych potrzeb ludności w drodze świadczenia usług powszechnie dostępnych.

6 M. Szydło, Ustawa o gospodarce komunalnej. Komentarz, Warszawa 2008, s. 137-140. 
że wszystkie zadania własne realizują cel w postaci zaspokajania zbiorowych potrzeb wspólnoty samorządowej i są objęte zakresem gospodarki komunalnej ${ }^{7}$.

Ustawa o samorządzie gminnym (art. 7 ust. 1) w otwartym katalogu obejmującym 22 pozycje wylicza rodzaje zadań własnych, które gmina powinna realizować. Należą do nich m.in. zadania dotyczące wodociągów i zaopatrzenia w wodę, kanalizacji, usuwania i oczyszczania ścieków komunalnych, utrzymania czystości i porządku oraz urządzeń sanitarnych, wysypisk i unieszkodliwiania odpadów komunalnych, lokalnego transportu zbiorowego (art. 7 ust. 1 pkt 3, 4 u.s.g.).

Zadania własne mogą być realizowane w różnych formach. U.s.g. w art. 9 ust. 1 stanowi, że gmina w celu wykonywania zadań może tworzyć jednostki organizacyjne. U.g.kom. wskazuje przykładowo na dwie formy wykonywania zadań: samorządowy zakład budżetowy oraz spółkę prawa handlowego. Treść przytoczonych przepisów pozwala na przyjęcie, że „forma” realizowania zadania oznacza w tym kontekście jednostkę organizacyjną lub osobę prawną określonego rodzaju. Nie można wykluczyć korzystania przez gminę z innych form niż zakłady budżetowe i spółki prawa handlowego. Możliwość tworzenia innego rodzaju jednostek organizacyjnych i osób prawnych (lub przystępowania do tych ostatnich) wynika z przepisów szczególnych. Innymi formami, za pośrednictwem których gminy mogą realizować swoje zadania, są: jednostki budżetowe, instytucje kultury, spółdzielnie, fundacje, stowarzyszenia ${ }^{8}$.

Z odrębnych przepisów wynika również możliwość realizacji zadań z zakresu gospodarki komunalnej w drodze współdziałania między j.s.t. poprzez tworzenie związków j.s.t. i zawierania porozumień.

Celem artykułu jest analiza sposobów realizowania zadań własnych przez gminy w świetle wybranych ustaw szczególnych oraz określenie, jaki wpływ na gminną gospodarkę komunalną mają analizowane regulacje. W rozważaniach uwaga zostanie poświęcona ustawom: o zbiorowym

\footnotetext{
7 M. Szydło, Ustawa..., s. 28; C. Banasiński, M. Kulesza, Ustawa o gospodarce komunalnej. Komentarz, Warszawa 2002, s. 14.

8 W. Gonet, Uwagi o formach prowadzenia gospodarki komunalnej, „Samorząd Terytorialny” 2008, nr 7-8, s. 65.
} 
zaopatrzeniu w wodę i zbiorowym odprowadzaniu ścieków ${ }^{9}$, o utrzymaniu czystości i porządku w gminach ${ }^{10}$ i o publicznym transporcie zbiorowym ${ }^{11}$.

\section{Realizacja przez gminę zadania zbiorowego zaopatrzenia $w$ wodę i zbiorowego odprowadzania ścieków}

Zbiorowe zaopatrzenie w wodę i zbiorowe odprowadzanie ścieków jest zadaniem własnym gminy ${ }^{12}$. Zasady prowadzenia tej działalności są określone w ustawie o zbiorowym zaopatrzeniu w wodę i zbiorowym odprowadzaniu ścieków. Ustawa ta nie zawiera żadnych regulacji odnośnie trybu wyboru podmiotu, który miałby realizować zadania objęte jej zakresem. Z jej przepisów (art. 16) wynika jednak istotny warunek niezbędny do podjęcia działalności w postaci uzyskania zezwolenia wydawanego przez wójta (burmistrza, prezydenta miasta) w drodze decyzji administracyjnej.

Ustawa definiuje zbiorowe zaopatrzenie w wodę i zbiorowe odprowadzanie ścieków jako działalność polegającą odpowiednio na: ujmowaniu, uzdatnianiu i dostarczaniu wody lub odprowadzaniu i oczyszczaniu ścieków, prowadzoną przez przedsiębiorstwo wodociągowo-kanalizacyjne (art. 2 pkt. 20, 21). Przedsiębiorstwem wodociągowo-kanalizacyjnym może być przedsiębiorca w rozumieniu przepisów o swobodzie działalności gospodarczej, jeżeli prowadzi działalność gospodarczą w zakresie zbiorowego zaopatrzenia $\mathrm{w}$ wodę lub zbiorowego odprowadzania ścieków, oraz gminne jednostki organizacyjne nieposiadające osobowości prawnej, prowadzące tego rodzaju działalność (art. 2 pkt. 4). Przepis ten dopuszcza kilka form prawnych przedsiębiorstwa wodociągowo-kanalizacyjnego. Może być nim gminna jednostka organizacyjna nieposiadająca osobowości prawnej lub przedsiębiorca. Przedsiębiorcą może być gminna spółka prawa handlowego. Pojęcie przedsiębiorcy na gruncie

\footnotetext{
Ustawa z dnia 7 czerwca 2001 r. (tekst jedn. Dz.U. z 2015 r., poz. 139 ze zm.).

Ustawa z dnia 13 września 1996 r. (tekst jedn. Dz.U. z 2016 r., poz. 250 ze zm.).

Ustawa z dnia 16 grudnia 2010 r. (Dz.U. z 2015 r. poz. 1440 ze zm.).

Art. 7 ust. 2 pkt. 3 u.s.g., art. 3 ust. 1 ustawy o zbiorowym zaopatrzeniu w wodę i zbiorowym odprowadzaniu ścieków.
} 
ustawy o swobodzie działalności gospodarczej obejmuje również podmioty prywatne prowadzące działalność gospodarczą. Ponadto art. 17b pkt. 5 ustawy wskazuje również na możliwość prowadzenia działalności bezpośrednio przez gminę ${ }^{13}$.

Warunkiem prowadzenia działalności w zakresie zbiorowego zaopatrzenia w wodę lub zbiorowego odprowadzania ścieków jest uzyskanie zezwolenia. Zezwolenie jest wydawane w drodze decyzji administracyjnej przez wójta (burmistrza, prezydenta miasta) (art. 16 ust. 1). Zezwolenie wydawane jest na wniosek przedsiębiorstwa wodociągowo-kanalizacyjnego spełniającego wymogi określone w ustawie: 1) mającego na terytorium Rzeczypospolitej Polskiej siedzibę i adres, oddział lub przedstawicielstwo w rozumieniu przepisów o działalności gospodarczej, 2) posiadającego środki finansowe lub które udokumentuje możliwość ich uzyskania w wysokości niezbędnej do prawidłowego prowadzenia zbiorowego zaopatrzenia w wodę i zbiorowego odprowadzania ścieków, 3) posiadającego środki techniczne odpowiednie do zakresu działalności w zakresie zbiorowego zaopatrzenia w wodę lub zbiorowego odprowadzania ścieków.

Obowiązek uzyskania zezwolenia nie dotyczy gminnych jednostek organizacyjnych nieposiadających osobowości prawnej, prowadzących działalność na obszarze własnej gminy (art. 16 ust. 3). A contrario, obowiązek uzyskania zezwolenia dotyczy podmiotów będących przedsiębiorstwami wodociągowo-kanalizacyjnymi w rozumieniu ustawy, działającymi w innych formach prawnych niż gminne jednostki organizacyjne nieposiadające osobowości prawnej. Oczywistym jest, że zezwolenia nie wymaga również bezpośrednie prowadzenie działalności przez gminę poprzez wydziały urzędu gminy.

Z uwagi charakter prawny zezwolenia istotnego znaczenia dla gminy nabiera kwestia wyboru, w jakiej formie prawnej miałaby być prowadzona działalność w zakresie zbiorowego zaopatrzenia w wodę i zbiorowego odprowadzania ścieków. Ustawa kształtuje bowiem zezwolenie jako instytucję o trwałym charakterze i ogranicza możliwość odmowy jego wy-

13 Potwierdza to wyrok NSA z dnia 16 listopada 2006 r., II OSK 1365/05, CBOSA. 
dania oraz „odebrania” go przedsiębiorcy do przypadków ściśle określonych. Zgodnie z art. 18b ust. 1-2 zezwolenie wydaje się na czas nieoznaczony. Możliwość wydania zezwolenia na czas oznaczony istnieje jedynie na wniosek przedsiębiorstwa wodociągowo-kanalizacyjnego. Zatem w świetle powyższych przepisów wójt nie może z własnej inicjatywy wydać zezwolenia na czas oznaczony.

Ustawa przewiduje zamknięty katalog przyczyn uzasadniających odmowę wydania zezwolenia. Może ona nastąpić w przypadku, gdy: 1) przedsiębiorstwo wodociągowo-kanalizacyjne nie spełnia warunków wykonywania działalności objętej zezwoleniem określonych w ustawie, 2) ze względu na zagrożenie obronności lub bezpieczeństwa państwa, 3) ze względu na zagrożenie życia lub zdrowia ludzi lub zagrożenie środowiska naturalnego, 4) jeżeli w wyniku postępowania na podstawie przepisów o zamówieniach publicznych zawarta została przez gminę umowa na prowadzenie zbiorowego zaopatrzenia w wodę lub zbiorowego odprowadzania ścieków z innym przedsiębiorstwem wodociągowokanalizacyjnym, 5) jeżeli na obszarze gminy działalność w zakresie zbiorowego zaopatrzenia w wodę lub zbiorowego odprowadzania ścieków prowadzi gmina lub jej jednostka organizacyjna nieposiadająca osobowości prawnej.

Sposób ukształtowania instytucji, jaką jest zezwolenie na prowadzenie działalności w zakresie zbiorowego zaopatrzenia w wodę lub zbiorowego odprowadzania ścieków, sprawia, że można uznać ją za działalność prowadzoną w warunkach monopolu prawnego ${ }^{14}$. Nie jest możliwa sytuacja, w której działalność objęta zezwoleniem byłaby prowadzona przez więcej niż jeden podmiot. Złożenie wniosku o wydanie zezwolenia skutkowałoby w tej sytuacji odmową na podstawie art. 17b pkt. 4 lub pkt. 5 ustawy.

Zezwolenie jest wydawane w formie decyzji administracyjnej. Przesłanki odmowy wydania zezwolenia zostały ściśle określone w analizowanej ustawie. W zakresie wydawania zezwolenia wójt nie korzysta za-

14 M. Szydło, Ustawa..., s. 279. Autor wskazuje na względny charakter monopolu w przypadku gminy, która może wykonywać zadanie sama, ale również może powierzyć je innemu podmiotowi na podstawie umowy. 
tem z uznania administracyjnego ${ }^{15}$. Termin wydania zezwolenia będącego decyzją administracyjną określa k.p.a. Jego naruszenie w świetle art. 18b ust. 3 ustawy nie jest traktowane jako wydanie decyzji zgodnie $\mathrm{z}$ wnioskiem przedsiębiorcy (choć może wywierać skutki na gruncie k.p.a. i innych ustaw, np. związane z bezczynnością organu). Wskazuje to, że wójt ma pewne możliwości niedopuszczenia przedsiębiorstwa do prowadzenia działalności objętej ustawą. Jednak z drugiej strony brzmienie ustawy sugeruje, że w sytuacji, w której gmina sama (lub poprzez swoje jednostki organizacyjne lub spółki, którym dała zezwolenie) nie prowadzi działalności i nie prowadzi jej także żaden inny podmiot, wójt nie mógłby odmówić wydania zezwolenia przedsiębiorstwu spełniającemu warunki określone w art. 17b pkt. 1-3 ustawy, które złożyłoby wniosek.

Można zastanawiać się, czy gmina mogłaby zrezygnować z usług przedsiębiorstwa wodociągowo-kanalizacyjnego, z którym zawarła umowę, o której mowa w art. 17b pkt. 4 ustawy. Mogłoby być to trudne. Żaden artykuł ustawy nie przewiduje cofnięcia zezwolenia (które może być wydane na czas nieokreślony) w sytuacji, gdy gmina utworzyła własną jednostkę organizacyjną nieposiadającą osobowości prawnej lub własną spółkę prawa handlowego.

Zgodnie $\mathrm{z}$ art. 21 ust. 1 ustawy przedsiębiorstwo wodociągowo-kanalizacyjne opracowuje wieloletni plan rozwoju i modernizacji urządzeń wodociągowych i urządzeń kanalizacyjnych będących w jego posiadaniu. Plan określa w szczególności: planowany zakres usług wodociągowo-kanalizacyjnych, przedsięwzięcia rozwojowo-modernizacyjne w poszczególnych latach, przedsięwzięcia racjonalizujące zużycie wody oraz wprowadzanie ścieków, nakłady inwestycyjne w poszczególnych latach oraz sposoby finansowania planowanych inwestycji (art. 21 ust. 2).

Plan powinien być zgodny z kierunkami rozwoju gminy określonymi w studium uwarunkowań i kierunków zagospodarowania przestrzennego gminy, z ustaleniami miejscowych planów zagospodarowania przestrzennego oraz ustaleniami zezwolenia wydanego temu przedsiębiorstwu na prowadzenie zbiorowego zaopatrzenia w wodę i zbiorowego odprowa-

15 B. Rakoczy, Zbiorowe zaopatrzenie $w$ wodę i zbiorowe odprowadzanie ścieków w praktyce przedsiębiorstw wodociagowo-kanalizacyjnych, Bydgoszcz 2012, s. 100. 
dzania ścieków (art. 21 ust. 3). Przedsiębiorstwo wodociągowokanalizacyjne przedkłada plan wójtowi, który sprawdza, czy plan jest zgodny z powyższymi uchwałami i zezwoleniem. Następnie plan jest uchwalany przez radę gminy w terminie 3 miesięcy od dnia przedłożenia planu wójtowi (burmistrzowi, prezydentowi miasta).

Obowiązek opracowania planu nie dotyczy przedsiębiorstw wodociągowo-kanalizacyjnych, które nie planują budowy urządzeń wodociągowych lub urządzeń kanalizacyjnych (art. 21 ust. 7). Przytoczone regulacje wskazują, że rada gminy posiada kontrolę nad działalnością przedsiębiorstwa wodociągowo-kanalizacyjnego w zakresie jego inwestycji.

Taryfy za zbiorowe zaopatrzenie w wodę i zbiorowe odprowadzanie ścieków są określane przez przedsiębiorstwo wodociągowo-kanalizacyjne na 1 rok. Wysokość opłat jest zróżnicowana dla poszczególnych grup odbiorców usług. Opłaty uwzględniają niezbędne przychody przedsiębiorstwa, które są ustalane na zasadach określonych w art. 20 ust. 4 ustawy. Taryfy podlegają zatwierdzeniu w drodze uchwały rady gminy. Przed podjęciem uchwały przez radę gminy muszą zostać zweryfikowane przez wójta pod względem poprawności przyjęcia określonych kwot (przedsiębiorstwo przedstawia wójtowi wniosek w tej sprawie, dołączając szczegółową kalkulację cen i stawek opłat oraz plan rozwoju i modernizacji urządzeń wodociągowych i kanalizacyjnych). Rada gminy może odmówić zatwierdzenia taryf jedynie w sytuacji, jeżeli zostały one sporządzone niezgodnie z przepisami (art. 24 ust. 5). Powyższa regulacja wskazuje, że przedsiębiorstwo wodociągowo-kanalizacyjne nie określa swobodnie wysokości taryf. Zasady ich obliczania określa ustawa, a ostateczną decyzję o ich zatwierdzeniu podejmuje rada gminy poprzez stosowną uchwałę.

Przepisy ustawy o zbiorowym zaopatrzeniu w wodę i zbiorowym odprowadzaniu ścieków wskazują, że działalność przedsiębiorstwa wodociągowo-kanalizacyjnego w zakresie inwestycji, planów i taryf musi uwzględniać reguły ustanowione przez gminę. Działalność przedsiębiorstwa pozostaje pod kontrolą gminy, przedsiębiorstwo pozostaje w funkcjonalnej zależności od gminy.

Kwestią nieuregulowaną w ustawie o zbiorowym zaopatrzeniu w wodę i zbiorowym odprowadzaniu ścieków jest własność infrastruktury 
wodociągowej i kanalizacyjnej. Treść ustawy wskazuje, że może ona stanowić własność gminy albo własność przedsiębiorstwa wodociągowo-kanalizacyjnego: art. 2 pkt. 7 definiuje sieć wodociągową lub kanalizacyjną jako przewody będące „w posiadaniu” przedsiębiorstwa wodociągowo-kanalizacyjnego. O posiadaniu urządzeń wodociągowych i kanalizacyjnych przez przedsiębiorstwo mówi też art. 21 ust. 1 ustawy. Art. 31 ust. 1 mówi natomiast o możliwości odpłatnego przekazywania urządzeń wodociągowych i kanalizacyjnych wybudowanych ze środków prywatnych na rzecz gminy lub przedsiębiorstwa wodociągowo-kanalizacyjnego na warunkach uzgodnionych w umowie. Powołane przepisy wskazują, że kwestia własności infrastruktury może być ukształtowana w różny sposób.

Dane empiryczne wskazują, że działalność w zakresie zbiorowego zaopatrzenia w wodę i zbiorowego odprowadzania ścieków jest prowadzona przez przedsiębiorstwa wodociągowo-kanalizacyjne działające w różnych formach prawnych. Według stanu na koniec 2009 r. istniało w tym sektorze ponad 500 spółek komunalnych ${ }^{16}$. Ponadto działają tu gminne zakłady budżetowe i jednostki budżetowe. W mniejszych gminach działalność bywa wykonywana bezpośrednio poprzez wydziały urzędu gminy ${ }^{17}$. W bardzo ograniczonym zakresie podejmowane są próby nawiązywania współpracy z przedsiębiorcami prywatnymi ${ }^{18}$.

Powyższe dane wskazują, że dominującym modelem realizowania zadań z zakresu zbiorowego zaopatrzenia w wodę i zbiorowego odprowadzania ścieków jest model oparty o uzyskanie zezwolenia (w drodze de-

16 D. Andrzejewski, H. Goska, M. Klupczyński, Ł. Knade, A. Kozłowska, R. Majewski, P. Szymańska, M. Woźniak, Kondycja finansowa spółek komunalnych w Polsce 2013, s. 2. http://www.curulis.pl/img/download/raport_spolki_komunalne_2013_09.pdf, (dostęp: 04.09.2016 r.).

17 Informacja o wynikach kontroli NIK, Prowadzenie przez gminy zbiorowego zaopatrzenia w wodę i zbiorowego odprowadzania ścieków, Warszawa 2011, s. 13 wskazuje, że na 14 gmin objętych badaniem w 9 działały gminne spółki, w 2 gminne zakłady budżetowe, a w 3 zadanie zbiorowego zaopatrzenia w wodę i zbiorowego odprowadzania ścieków realizowano poprzez wydziały lub referaty urzędu gminy.

18 W latach 2009-2014 w 17 gminach próbowano nawiązać współpracę z partnerami prywatnymi w oparciu o koncesję, z czego w 8 przypadkach zawarto umowę. PARP, Raport dotyczq̨cy rynku ppp w Polsce w obszarze gospodarki odpadami, Warszawa 2015, s. 8-37. Innym przykładem współpracy w formule PPP są miasta Gdańsk, Sopot i Łódź. http://www.sng.com.pl/firma/rodowod.aspx (dostęp: 27.08.2016 r.). 
cyzji administracyjnej) i o tworzenie własnych jednostek organizacyjnych (lub odpowiednio spółek komunalnych) przez gminy. Model ten odpowiada działalności o szczególnym charakterze, zaspokajającej elementarną potrzebę dostępu do wody, prowadzonej w warunkach monopolu naturalnego. Dostęp podmiotów prywatnych do prowadzenia działalności jest możliwy, ale ograniczony wymogiem uzyskania zezwolenia, a więc uzależniony od decyzji organów gminy ${ }^{19}$. Zezwolenie $\mathrm{z}$ jednej strony jest instrumentem zapewniającym gminie kontrolę nad sektorem działalności obejmującej zbiorowe zaopatrzenie $\mathrm{w}$ wodę i zbiorowe odprowadzanie ścieków, z drugiej jednak strony jest również trwałą gwarancją możliwości prowadzenia działalności przez podmiot, który raz je uzyskał (pod warunkiem, że przestrzega warunków, na jakich zezwolenie zostało udzielone).

\section{Realizacja zadań w zakresie utrzymania czystości i porządku w gminie}

Zadanie polegające na utrzymaniu czystości i porządku w gminie jest obligatoryjnym zadaniem własnym gminy o charakterze użyteczności publicznej. Zasady jego realizacji określa ustawa z dnia 13 września 1996 r. o utrzymaniu czystości i porządku w gminach ${ }^{20}$. Ustawa ta w art. 3 ust. 2-3 precyzuje, jakie działania powinna podejmować gmina w ramach ustawy. Do działań tych należą (m.in.):

1. tworzenie warunków do wykonywania prac związanych z utrzymaniem czystości i porządku na terenie gminy lub zapewnienie wykonania tych prac przez tworzenie odpowiednich jednostek organizacyjnych,

2. zapewnienie budowy, utrzymania i eksploatacji własnych lub wspólnych z innymi gminami: regionalnych instalacji do przetwarzania odpadów komunalnych, stacji zlewnych, instalacji i urządzeń do zbierania, transportu i unieszkodliwiania zwłok zwierzęcych oraz szaletów publicznych,

19 M. Szydło, Ustawa..., s. 271, 279-280.

20 Dz.U. z 2016 r., poz. 250, dalej: u.c.p.g. 
3. objęcie wszystkich właścicieli nieruchomości na terenie gminy systemem gospodarowania odpadami komunalnymi,

4. nadzorowanie gospodarowania odpadami komunalnymi, w tym realizacji zadań powierzonych podmiotom odbierającym odpady komunalne od właścicieli nieruchomości,

5. ustanowienie selektywnego zbierania odpadów komunalnych obejmującego określone w ustawie frakcje (rodzaje) odpadów oraz tworzenie punktów selektywnego zbierania odpadów komunalnych w sposób zapewniający łatwy dostęp dla wszystkich mieszkańców gminy,

6. zapewnienie osiągnięcia odpowiednich poziomów recyklingu,

7. działania informacyjne i edukacyjne,

8. zapobieganie bezdomności zwierząt,

9. zapewnienie zbierania, transportu i unieszkodliwiania zwłok bezdomnych zwierząt oraz współdziałanie z przedsiębiorcami podejmującymi działalność w tym zakresie.

Niektóre z wyżej wymienionych działań ustawodawca formułuje w ten sposób, że gmina jest zobowiązana „zapewnić” ich realizację w określony sposób albo „tworzyć warunki” do ich realizacji (np. w przypadku działań wymienionych w punktach 1 i 2). Ustawa (odmiennie niż ustawa o zbiorowym zaopatrzeniu w wodę i zbiorowym odprowadzaniu ścieków) nie zawiera definicji przedsiębiorstwa prowadzącego działalność objętą jej zakresem. Działalność objętą zakresem ustawy zasadniczo mogą zatem prowadzić wszystkie podmioty, które spełnią warunki w niej określone. Mogą to być jednostki organizacyjne gminy, gminne osoby prawne, a także przedsiębiorcy prywatni. W przypadku niektórych zadań ustawa przewiduje określony tryb wyboru wykonawców, w innych zaś nie zawiera regulacji w tym zakresie.Zadaniem, w przypadku którego ustawodawca przewiduje określony tryb wyboru wykonawcy, jest odbieranie odpadów komunalnych. Ustawa przewiduje inne rozwiązania prawne w zależności od tego, czy na nieruchomościach zamieszkują mieszkańcy, czy nie. Na wskazaną różnorodność nakładają się też zmiany stanu prawnego.

Przed 2011 r. właściciele nieruchomości sami decydowali, z którym przedsiębiorstwem zawrą umowę na odbiór odpadów komunalnych. 
Obowiązywała zatem konkurencja między przedsiębiorstwami. Wadą tego rozwiązania były zjawiska takie jak dzikie wysypiska śmieci.

W 2011 r. weszła w życie zmiana tego systemu, polegająca na uczynieniu gminy odpowiedzialną na zorganizowanie odbioru odpadów komunalnych z nieruchomości, na których zamieszkują mieszkańcy. W omawianym stanie prawnym wójt (burmistrz, prezydent miasta) był obowiązany zorganizować przetarg na odbieranie odpadów komunalnych od właścicieli nieruchomości, na których zamieszkują mieszkańcy. Spółki z udziałem gminy mogły odbierać odpady komunalne od właścicieli nieruchomości na zlecenie gminy w przypadku, gdy zostały wybrane w drodze przetargu (art. 6e u.c.p.g.). Wprowadzono zatem model oparty o bezwzględny obowiązek zorganizowania przetargu na wybór wykonawcy zadania odbioru odpadów komunalnych z nieruchomości zamieszkałych (nawet w sytuacji posiadania przez gminę własnej spółki lub jednostki organizacyjnej nieposiadającej osobowości prawnej).

Natomiast odbiór odpadów z nieruchomości, na których nie zamieszkują mieszkańcy, był zadaniem fakultatywnym, o realizacji którego mogła postanowić rada gminy w drodze uchwały. W tym przypadku ustawodawca nie przewidział obowiązku zorganizowania przetargu na odbiór odpadów komunalnych.

W stanie prawnym obowiązującym od 1 stycznia 2017 r. ${ }^{21}$ sytuacja ulega istotnej zmianie w przypadku odbioru odpadów komunalnych zarówno z nieruchomości, na których zamieszkują mieszkańcy, jak i z nieruchomości niezamieszkałych. W przypadku odbioru odpadów komunalnych z nieruchomości, na których zamieszkują mieszkańcy, ustawodawca rezygnuje $\mathrm{z}$ obowiązku zorganizowania przetargu na rzecz obowiązku udzielenia zamówienia publicznego. Zmiana ta ma istotne znaczenie, ponieważ umożliwia powierzenie przez gminę odbioru odpadów komunalnych gminnym osobom prawnym (spółkom z udziałem gminy) w trybie określonym w ustawie Prawo zamówień publicznych, ale innym niż przetarg. Trybem, w którym gminy będą mogły od 1 stycznia 2017 r. powierzać odbiór odpadów komunalnych „swoim” spółkom, jest udzielenie

21 Zmiana nastąpiła na nocy art. 7 pkt. 4 ww. ustawy z dnia 22 czerwca 2016 r. 
zamówienia z wolnej ręki ${ }^{22}$. Polega ono na zawarciu umowy z wykonawcą wybranym przez gminę bez stosowania przetargu czy innego trybu zakładającego konkurencję między wykonawcami. Jest to możliwe wyłącznie w przypadkach określonych ustawą P.z.p., do której ustawodawca wprowadził wypracowaną $\mathrm{W}$ prawie UE koncepcję tzw. zamówień in-house $e^{23}$.

Zamówienia in-house to zamówienia wewnętrzne, zlecane przez zamawiającego wykonawcy będącemu podmiotem zależnym lub kontrolowanym przez zamawiającego. W orzecznictwie TSUE przyjęto, że zamawiający nie musi dokonywać wyboru wykonawcy w trybie przetargowym, jeżeli łącznie spełnione są dwa kryteria: 1) zamawiający sprawuje nad wykonawcą kontrolę analogiczną do kontroli sprawowanej nad własnymi służbami, 2) zasadnicza część działalności wykonawcy jest realizowana na rzecz zamawiającego ${ }^{24}$.

Zgodnie ze znowelizowanym art. 67 P.z.p. (pkt. 12) zamawiający może udzielić zamówienia z wolnej ręki, jeżeli zamówienie udzielane jest przez zamawiającego będącego jednostką sektora finansów publicznych lub osobą prawną spoza sektora finansów publicznych (art. 3 ust. 1 pkt. 1 -3a P.z.p.), osobie prawnej, jeżeli spełnione są łącznie następujące warunki:

a) zamawiający sprawuje nad tą osobą prawną kontrolę, odpowiadającą kontroli sprawowanej nad własnymi jednostkami, polegającą na dominującym wpływie na cele strategiczne oraz istotne decyzje dotyczące zarządzania sprawami tej osoby prawnej; warunek ten jest również spełniony, gdy kontrolę taką sprawuje inna osoba prawna kontrolowana przez zamawiającego w taki sam sposób,

b) ponad $90 \%$ działalności kontrolowanej osoby prawnej dotyczy wykonywania zadań powierzonych jej przez zamawiającego sprawują-

22 Uzasadnienie do projektu ustawy o zmianie ustawy - Prawo zamówień publicznych oraz niektórych innych ustaw, przedstawionego Sejmowi 24 marca 2016 r., druk sejmowy nr 366.

23 Uzasadnienie do projektu ustawy zmianie ustawy - Prawo zamówień publicznych oraz niektórych innych ustaw (druk 366).

24 Wyrok ETS z dnia 18 listopada 1999 r., Teckal Srl przeciwko Commune di Viano i Azienda Gas-Acqua Consorziale (AGAC) di Reggio Emilia, sprawa C-107/98. 
cego kontrolę lub przez inną osobę prawną, nad którą ten zamawiający sprawuje kontrolę, o której mowa w lit. a,

c) w kontrolowanej osobie prawnej nie ma bezpośredniego udziału kapitału prywatnego.

Omawiana nowelizacja P.z.p. i u.c.p.g., zwalniając gminy z obowiązku powierzania $\mathrm{w}$ drodze przetargu odbioru odpadów $\mathrm{z}$ nieruchomości zamieszkałych, wprowadza natomiast obowiązek zorganizowania przetargu na odbiór odpadów komunalnych z nieruchomości niezamieszkałych, na których powstają odpady komunalne - jeżeli rada gminy zdecydowałaby się na podjęcie się przez gminę wykonywania tego zadania. Odczytanie intencji przyświecającej ustawodawcy przy wprowadzaniu tego wymogu nie jest łatwe. Stanowi on wyłom w dopiero co wprowadzonej regule in-house, w rezultacie którego odbiór odpadów z nieruchomości zamieszkałych będzie mogła realizować w trybie zamówienia z wolnej ręki gminna osoba prawna, a odbiór odpadów z nieruchomości niezamieszkałych - inny podmiot, wyłoniony w przetargu.

Analiza przepisów u.c.p.g. wskazuje, że od 2011 r. przewiduje ona model wykonywania zadania odbioru odpadów komunalnych oparty na zawarciu umowy przez przedsiębiorcę z jednostką samorządu terytorialnego. Jest to umowa o udzielenie zamówienia publicznego. Wykonawca może być wyłoniony w trybie przetargu (w przypadku odbioru odpadów komunalnych z nieruchomości zamieszkałych do 31 grudnia 2016 r. oraz w przypadku odbioru odpadów komunalnych z nieruchomości niezamieszkałych po 31 grudnia 2016 r.) lub w innym trybie przewidzianym P.z.p. (w przypadku odbioru odpadów komunalnych z nieruchomości zamieszkałych po 31 grudnia 2016 r.).

Obowiązek organizowania przetargów wzbudził kontrowersje z uwagi na zagrożenie dla gminnych spółek, dla których przegrana w przetargu oznacza utratę podstawy do dalszego funkcjonowania ${ }^{25}$, z czym wiąże się marnowanie majątku pochodzącego ze środków publicznych oraz zasobów kadrowych, które mogłyby służyć gminie. Wydaje się, że gmina,

25 J. Wantoch-Rekowski, Spółki komunalne a Prawo zamówień publicznych [w:] A. Borodo (red.), Aktualne problemy rozwoju gospodarczego gmin i powiatów, Włocławek 2006, s. 61. 
która musiałaby wybierać przedsiębiorstwo oczyszczania w drodze przetargu, a nie miałaby wcześniej utworzonej własnej spółki, obawiałaby się tworzyć ją od podstaw i wyposażać w majątek.

Według stanu na koniec 2009 r. istniało ok. 200 spółek komunalnych w sektorze oczyszczania ${ }^{26}$. Po wejściu w życie nowelizacji u.c.p.g. z 2011 r. powinny one brać udział w przetargach na odbiór odpadów komunalnych. Sytuacje, w których spółki te przegrywały konkurencję z prywatnymi przedsiębiorcami, nie należały do rzadkości ${ }^{27}$.

Należy także wspomnieć, że odbiorem odpadów komunalnych mogą również zajmować się gminne zakłady budżetowe (oraz jednostki budżetowe). Są to podmioty nieposiadające osobowości prawnej. W literaturze ${ }^{28}$ i w orzecznictwie ${ }^{29}$ przyjmuje się, że nie mogą one z tego powodu skutecznie zawrzeć umowy cywilnoprawnej ze swoją macierzystą gminą. Udzielenie zamówienia publicznego następuje poprzez zawarcie umowy cywilnoprawnej, stąd przepisy przewidujące obowiązek udzielenia zamówienia publicznego na odbiór odpadów komunalnych stawiają zakłady budżetowe w trudnej sytuacji ${ }^{30}$.

26 D. Andrzejewski, H. Goska, M. Klupczyński, Ł. Knade, A. Kozłowska, R. Majewski, P. Szymańska, M. Woźniak, Kondycja finansowa spółek komunalnych w Polsce 2013, s. 2.

27 Po wprowadzeniu obowiązku przetargowego zwycięzcami przetargów w ponad 76\% okazały się spółki prywatne, w $16 \%$ - spółki ze stuprocentowym udziałem gminy, w 7\% spółki z udziałem gminy poniżej 100\%. D. Andrzejewski, H. Goska, M. Klupczyński, Ł. Knade, A. Kozłowska, R. Majewski, P. Szymańska, M. Woźniak, Kondycja finansowa spółek komunalnych w Polsce 2013, s. 3. M. Szydło, Ustawa..., s. 201-202.

29 Wyrok WSA w Łodzi z dnia 9 lipca 2013 r., sygn. I SA/Łd 461/13, wyrok WSA w Bydgoszczy z dnia 18 lutego 2015 r., sygn. I SA/Bd 1259/14.

30 Na marginesie można zauważyć, że cały czas obowiązuje art. 14 pkt. 3 ustawy z dnia 27 sierpnia 2009 r. o finansach publicznych, zgodnie z którym zadania własne j.s.t. w zakresie usuwania i oczyszczania ścieków komunalnych, utrzymania czystości i porządku oraz urządzeń sanitarnych, wysypisk i unieszkodliwiania odpadów komunalnych mogą być wykonywane przez samorządowe zakłady budżetowe. 


\section{Realizacja zadań z zakresu publicznego transportu zbiorowego}

Zgodnie z art. 7 pkt. 4 u.s.g. zadania własne gminy obejmują sprawy lokalnego transportu zbiorowego. Zasady wykonywania tej działalności reguluje ustawa o publicznym transporcie zbiorowym ${ }^{31}$. Ustawa ta określa, które zadania z zakresu publicznego transportu zbiorowego są zadaniami własnymi gminy. W świetle art. 18 u.p.t.z. obejmują one budowę, przebudowę i remont przystanków, wiat, dworców lub innych budynków służących pasażerom i usytuowanych w obrębie dróg publicznych. Obok zadań własnych gmina wykonuje zadania wynikające z przyznania jej w u.p.t.z. statusu organizatora publicznego transportu zbiorowego. Gmina jest organizatorem publicznego transportu zbiorowego na linii komunikacyjnej albo sieci komunikacyjnej w gminnych przewozach pasażerskich, na własnym obszarze, lub - w przypadku, gdy wynika to z zawartego porozumienia międzygminnego - na obszarze gmin, które zawarły porozumienie (art. 7 ust. 1 pkt. 1 u.p.t.z.).

W świetle ustawy działalność w zakresie publicznego transportu zbiorowego mogą prowadzić podmioty, które określa ona jako „przewoźników” oraz „operatorów publicznego transportu zbiorowego”. Przewoźnikiem jest przedsiębiorca uprawniony do prowadzenia działalności gospodarczej w zakresie przewozu osób na podstawie potwierdzenia zgłoszenia przewozu, a w transporcie kolejowym - na podstawie decyzji o przyznaniu otwartego dostępu. Potwierdzenie zgłoszenia przewozu jest wydawane przez właściwego organizatora transportu zbiorowego w drodze decyzji administracyjnej. Potwierdzenie (lub wypis z niego) uprawnia do wykonywania publicznego transportu zbiorowego na określonej linii komunikacyjnej. Z art. 30 ust. 1 u.p.t.z. wynika, że potwierdzenie zgłoszenia przewozu dotyczy przewozów innych niż przewozy o charakterze użyteczności publicznej. W celu uzyskania potwierdzenia zgłoszenia przewozu, przedsiębiorca musi dokonać organizatorowi zgłoszenia przewozu i spełnić pewne wymogi określone w ustawie (m.in. uzgodnić zasa-

31 Ustawa z dnia 16 grudnia 2010 r. (tekst jedn. Dz.U. z 2015 r. poz. 1440 ze zm., dalej: u.p.t.z.). 
dy korzystania z przystanków i dworców z ich właścicielami lub zarządzającymi oraz spełniać warunki, o których mowa w art. 6 ustawy).

Operatorem publicznego transportu zbiorowego może być samorządowy zakład budżetowy oraz przedsiębiorca uprawniony do prowadzenia działalności gospodarczej w zakresie przewozu osób, który zawarł z organizatorem publicznego transportu zbiorowego umowę o świadczenie usług w zakresie publicznego transportu zbiorowego, na linii komunikacyjnej określonej w umowie (art. 4 ust. 1 pkt. 8 u.p.t.z.). Operator musi spełniać warunki, o których mowa w art. 6 ustawy.

Z powyższego wynika, że pojęcie „operatora publicznego transportu zbiorowego” i „przewoźnika” na gruncie ustawy jest odnoszone do rodzaju przewozów, które wykonują te podmioty. Zarówno przewoźnik, jak i operator powinni spełniać warunki określone w art. 6 u.p.t.z. Przewoźnik jednak wykonuje przewozy niebędące przewozami użyteczności publicznej i czyni to na podstawie potwierdzenia zgłoszenia przewozu, a operator wykonuje przewozy o charakterze użyteczności publicznej i czyni to na podstawie umowy zawartej z organizatorem publicznego transportu zbiorowego.

Do zadań organizatora należy planowanie rozwoju transportu, organizowanie publicznego transportu zbiorowego i zarządzanie publicznym transportem zbiorowym (art. 8). Każde z tych zadań obejmuje określone ustawą działania, wśród których na szczególną uwagę zasługują działania związane z przewozami o charakterze użyteczności publicznej. W ramach planowania rozwoju transportu rada gminy uchwala (w zależności od liczby mieszkańców, obowiązkowo lub fakultatywnie) plan zrównoważonego rozwoju transportu publicznego (,plan transportowy”), będący aktem prawa miejscowego. Projekt planu jest opracowywany przez wójta (burmistrza, prezydenta miasta). Plan transportowy określa m.in. sieć komunikacyjną, na której jest planowane wykonywanie przewozów o charakterze użyteczności publicznej, przewidywane finansowanie usług przewozowych, pożądany standard usług przewozowych w przewozach o charakterze użyteczności publicznej. Organizowanie publicznego transportu zbiorowego polega m.in. na przeprowadzeniu postępowania poprzedzającego zawarcie umowy z operatorami na wykonywanie przez nich przewozów o charakterze użyteczności publicznej oraz zawieraniu tych 
umów. Zarządzanie m.in. obejmuje negocjowanie i zmiany umów zawartych z operatorami.

Przewozem o charakterze użyteczności publicznej jest powszechnie dostępna usługa w zakresie publicznego transportu zbiorowego wykonywana przez operatora publicznego transportu zbiorowego w celu bieżącego i nieprzerwanego zaspokajania potrzeb przewozowych społeczności na danym obszarze. Przewozy te odbywają się na podstawie umowy zawartej pomiędzy operatorem a organizatorem publicznego transportu zbiorowego, zwanej umową o świadczenie usług w zakresie publicznego transportu zbiorowego, która przyznaje operatorowi prawo i zobowiązuje go do wykonywania określonych usług związanych z wykonywaniem przewozu o charakterze użyteczności publicznej (art. 4 ust. 1 pkt. 24 u.p.t.z.).

Zgodnie z art. 19 u.p.t.z., organizator dokonuje wyboru operatora w trybie:

- $\quad$ ustawy P.z.p.,

- $\quad$ ustawy o koncesji na roboty budowlane lub usługi,

- $\quad$ bezpośredniego (tzn. bez stosowania P.z.p. ani ustawy o koncesji) zawarcia umowy - gdy spełnione są warunki określone w art. 22 u.p.t.z. (np. wartość przedmiotu umowy poniżej określonego progu, zawarcie umowy z podmiotem wewnętrznym w rozumieniu przepisów UE).

Ponadto organizator może realizować przewozy w ramach publicznego transportu zbiorowego w formie samorządowego zakładu budżetowego (art. 19 ust. 2 u.p.t.z.). Godną uwagi regulacją jest art. 4 ust. 2 pkt. 4 ustawy, zgodnie z którym przez umowę o świadczenie usług w zakresie publicznego transportu zbiorowego rozumie się również akt wewnętrzny określający warunki wykonywania usług w zakresie publicznego transportu zbiorowego przez samorządowy zakład budżetowy. Przywołane przepisy wskazują, że u.p.t.z. nie ogranicza możliwości działania gminy w wyborze operatora jedynie do zawierania umów cywilnoprawnych, ale wyraźnie wskazuje, obok nich, na możliwość wykonywania zadań w formie gminnego zakładu budżetowego.

Podmiotami, przy pomocy których gmina może realizować przewozy użyteczności publicznej, mogą być, oprócz zakładów budżetowych i pry- 
watnych przedsiębiorców, także gminne spółki prawa handlowego. $Z$ regulacji u.p.t.z. wynika, że powierzenie im wykonywania takich przewozów następuje w trybie wskazanym w art. 19 ustawy, tzn. w trybie P.z.p., ustawy o koncesji na roboty budowlane lub usługi, albo umowy bezpośrednio zawartej, o której mowa w art. 22 ustawy. Do spółek tych nie znajdzie zastosowania art. 4 ust. 2 pkt. 4 ustawy traktujący na równi z umową akt wewnętrzny określający warunki wykonywania usług w zakresie publicznego transportu zbiorowego, ponieważ dotyczy on jedynie zakładów budżetowych. Nie istnieje więc na gruncie u.p.t.z. możliwość powierzenia przez gminę własnej spółce wykonywania przewozów użyteczności publicznej inaczej niż poprzez zawarcie z nią umowy. Może być tu zastosowany każdy z trybów wymienionych w art. 19 u.p.t.z., w tym bezpośrednie zawarcie umowy, o którym mowa w art. 22. Jedną z przesłanek umożliwiających zawarcie bezpośrednio umowy przez gminę z własną spółką jest wykonywanie usług w zakresie publicznego transportu zbiorowego przez podmiot wewnętrzny w rozumieniu rozporządzenia (WE) nr 1370/2007 32 , powołany do świadczenia usług w zakresie publicznego transportu zbiorowego. Podmiotem wewnętrznym jest, zgodnie $\mathrm{z}$ art. 2 lit. j rozporządzenia, odrębna prawnie jednostka podlegająca kontroli właściwego organu lokalnego, a w przypadku grupy organów przynajmniej jednego właściwego organu lokalnego, analogicznej do kontroli, jaką sprawują one nad własnymi służbami. Ocena, czy jednostka podlega kontroli właściwego organu lokalnego, uwzględnia takie elementy, jak stopień reprezentowania w organach administrujących, zarządzających lub nadzorczych, stosowne postanowienia w statutach, strukturę własnościową, wpływ na decyzje strategiczne i indywidualne dotyczące zarządzania oraz sprawowanie nad nimi skutecznej kontroli. Posiadanie przez organ publiczny pełnej własności nie jest wymagane, o ile istnieje przewaga wpływu publicznego i sprawowanie kontroli można stwierdzić na podstawie innych kryteriów (art. 5 ust. 2 lit. a rozporządzenia). Rozporzą-

32 Rozporządzenie (WE) nr 1370/2007 Parlamentu Europejskiego i Rady z dnia 21 października 2007 r. dotyczące usług publicznych w zakresie kolejowego i drogowego transportu pasażerskiego oraz uchylające rozporządzenia Rady (EWG) nr 1191/69 i (EWG) nr 1107/70, Dz.Urz. UE L 315 z dnia 3 grudnia 2007 r., s.1. 
dzenie określa pewne warunki dotyczące działalności podmiotu wewnętrznego, m.in. powinien on świadczyć usługi na obszarze działania organu lokalnego (istnieje możliwość, że niektóre linie komunikacyjne lub elementy działalności mogą wykraczać poza ten obszar) oraz nie może brać udziału w przetargach na świadczenie usług publicznych w zakresie pasażerskiego transportu publicznego organizowanych poza terytorium tego właściwego organu lokalnego (art. 5 ust. 2 lit. b rozporządzenia).

W świetle powyższego gminna spółka prawa handlowego, na której działania gmina może, z racji posiadanego udziału kapitałowego lub kontrolowania organów spółki, wywierać podobny wpływ, jak na działania własnych służb, jest podmiotem wewnętrznym gminy. Do powierzenia jej wykonywania przewozów użyteczności publicznej gmina może zastosować art. 22 ust. 1 pkt. 2 u.p.t.z., czyli zawrzeć z tą spółką umowę bez stosowania przepisów P.z.p. czy ustawy o koncesji na roboty budowlane lub usługi.

Finansowanie przewozów o charakterze użyteczności publicznej może polegać m.in. na pobieraniu opłat przez organizatora lub operatora w związku z realizacją usług świadczonych w zakresie publicznego transportu zbiorowego, na przekazywaniu operatorowi publicznego transportu zbiorowego rekompensaty lub udostępnianiu mu przez organizatora środków transportu na realizację przewozów w zakresie publicznego transportu zbiorowego (art. 50 ust. 1 u.p.t.z.).

Rekompensatą są środki pieniężne lub inne korzyści majątkowe przyznane operatorowi publicznego transportu zbiorowego w związku ze świadczeniem usług w zakresie publicznego transportu zbiorowego (art. 4 ust. 1 pkt. 15 u.p.t.z.). Rekompensata może być przekazana z tytułu m.in. utraconych przez operatora przychodów w związku ze stosowaniem uprawnień do ulgowych przejazdów w publicznym transporcie zbiorowym (ustawowych lub ustanowionych przez danego organizatora), oraz poniesionych w związku ze świadczeniem przez operatora usług w zakresie publicznego transportu zbiorowego kosztów (art. 50 ust. 1 u.p.t.z.).

Sposób obliczania rekompensaty określa umowa zawarta przez organizatora z operatorem publicznego transportu zbiorowego (art. 25 ust. 3 pkt 15 w zw. z art. 22 ust. 3 u.p.t.z.). W niektórych przypadkach ustawa 
przewiduje, że umowa zawarta z podmiotem wewnętrznym w trybie art. 22 u.p.t.z. przybiera formę umowy koncesji na usługi (dotyczyć to może przypadku, gdy udział gminy (lub gmin) w akcjach/udziałach spółki jest mniejszy niż 100\%). Okoliczność, że umowa przybiera w takim przypadku formę umowy koncesji, wywiera wpływ na wysokość rekompensaty dla operatora. Zgodnie z art. 50 ust. 3 u.p.t.z., rekompensata nie może w takim przypadku prowadzić do odzyskania całości kosztów ponoszonych przez operatora w związku z wykonywaniem przewozów o charakterze użyteczności publicznej.

Rekompensata przysługuje operatorowi w przypadku, gdy wykaże on, że podstawą poniesionej straty $\mathrm{z}$ tytułu realizacji usług $\mathrm{w}$ zakresie publicznego transportu zbiorowego są utracone przychody i poniesione koszty, określone w art. 50 ust. 1 pkt 2 u.p.t.z., proporcjonalnie do poniesionej straty. Operator składa wniosek o rekompensatę, podając wysokość utraconych przychodów i poniesionych kosztów, obliczoną zgodnie z rozporządzeniem 1370/2007. Wniosek podlega weryfikacji przez organizatora. Przekazanie rekompensaty jest możliwe, jeżeli operator poniósł stratę i złożył wniosek o rekompensatę (art. 53 ust. 1 u.p.t.z.).

Do kosztów ponoszonych przez operatora wlicza się tzw. rozsądny zysk, który jest obliczany zgodnie z załącznikiem do rozporządzenia nr 1370/2007. Prawo do rozsądnego zysku nie przysługuje operatorowi wybranemu w trybie koncesji na roboty budowlane lub usługi, operatorowi będącemu podmiotem wewnętrznym, w przypadku którego umowa przybiera formę umowy o koncesję na usługi oraz operatorowi będącemu samorządowym zakładem budżetowym (art. 52 ust. 3 u.p.t.z.).

Ustawa o publicznym transporcie zbiorowym nie precyzuje, w jakiej formie ma być przekazywana rekompensata w przypadku, gdy miałaby być przekazywana z budżetu gminy. W przypadku rekompensat przekazywanych z budżetu państwa stanowi ona, że przybierają one formę dotacji, niekiedy wskazując przy tym rodzaj dotacji (art.: 55, 56, 80 u.p.t.z.). W odniesieniu do rekompensat przekazywanych z budżetu gminy brak analogicznych przepisów. Odwołanie się do przepisów u.f.p. dotyczących dotacji z budżetu j.s.t. również nie daje jednoznacznej odpowiedzi, czy 
rekompensata z budżetu gminy przybiera formę dotacji, i jakiego rodzaju jest to dotacja: podmiotowa, przedmiotowa czy celowa.

Dane empiryczne wskazują, że według stanu na koniec 2009 r. w Polsce działało ok. 150 spółek komunalnych w branży transportowej ${ }^{33}$. Spółki z branży transportowej na tle spółek z branż oczyszczania odpadów komunalnych oraz wodociągów i kanalizacji charakteryzują się najsłabszymi wynikami finansowymi ${ }^{34}$. Własne spółki posiadają zazwyczaj duże gminy. Są one dotowane z budżetu gmin, ponieważ wpływy ze sprzedaży biletów nie pokrywają ponoszonych przez spółki kosztów ${ }^{35}$. W różnych miastach funkcjonują odmienne rozwiązania: w Gdyni umowy zawarto z siedmioma operatorami, w tym zarówno spółkami miejskimi, jak prywatnymi przedsiębiorcami. Ok. 80\% rynku pozostaje pod kontrolą podmiotów komunalnych. Miejskie zakłady budżetowe są operatorami transportu publicznego m.in. w Łomży i w Zielonej Górze ${ }^{36}$.

\section{Podsumowanie}

Poczynione ustalenia wskazują, że gmina, realizując zadanie o charakterze użyteczności publicznej, ma co do zasady różne możliwości działania. Może tworzyć własne podmioty, zarówno jednostki organizacyjne nieposiadające osobowości prawnej, jak i osoby prawne - spółki prawa handlowego. Może również zawierać umowy cywilnoprawne z prywatnymi przedsiębiorcami. Na takie możliwości wskazują przepisy ustawy o samorządzie gminnym i ustawy o gospodarce komunalnej. Jednak ustawy te mają charakter ogólny i nie przesądzają, jakie rozwiązanie gmina może czy powinna zastosować w przypadku konkretnego zadania, odsyłając

33 D. Andrzejewski, H. Goska, M. Klupczyński, Ł. Knade, A. Kozłowska, R. Majewski, P. Szymańska, M. Woźniak, Kondycja finansowa spótek komunalnych w Polsce 2013, s. 2.

34 Ł. Knade, A. Sośnicka, H. Goska, M. Klupczyński, Kondycja finansowa spółek komunalnych $w$ Polsce 2014, s. 38, 42, http://www.curulis.pl/img/download/20141030_ raportspolkikomunalne_v13.pdf, (dostęp: 30.08.2016 r.) oraz D. Andrzejewski, H. Goska, M. Klupczyński, Ł. Knade, A. Kozłowska, R. Majewski, P. Szymańska, M. Woźniak, Kondycja finansowa spółek komunalnych w Polsce 2013, s. 7, 15-17, 33.

35 E. Żyła, Najlepsze pomysły na komunikację miejskq, „Wspólnota” 2013, nr 5, s. 27.

36 Tamże, s. 27-28. 
w tym zakresie do ustaw szczególnych. W ustawach tych zawarte są regulacje rozstrzygające, w jaki sposób dane zadanie ma być realizowane.

Analiza ustaw szczególnych pozwala na przyjęcie, że istnieje kilka modeli realizowania zadań z zakresu użyteczności publicznej przez gminy. Do głównych modeli należą model związany z uzyskaniem zezwolenia i model związany z zawarciem umowy cywilnoprawnej.

W modelu związanym z uzyskaniem zezwolenia podstawowym sposobem realizacji zadania jest tworzenie własnych podmiotów przy jednoczesnej reglamentacji dostępu do rynku podmiotów prywatnych. Model ten jest realizowany na gruncie ustawy o zbiorowym zaopatrzeniu w wodę i zbiorowym odprowadzaniu ścieków.

Model oparty o zawieranie umów cywilnoprawnych jest realizowany na gruncie ustawy o utrzymaniu czystości i porządku w gminach w odniesieniu do zadania polegającego na odbiorze odpadów komunalnych. Model ten do końca 2016 r. zakładał obligatoryjną konkurencję między wykonawcami zadania odbioru odpadów komunalnych z nieruchomości, na których zamieszkują mieszkańcy, poprzez obowiązek organizowania przetargów. Od 2017 r. zrezygnowano z tego obowiązku, dopuszczając wybór wykonawcy w trybie niekonkurencyjnym. Mimo tej zmiany utrzymano podstawową zasadę obowiązku zawarcia umowy cywilnoprawnej (o udzielenie zamówienia publicznego) jako koniecznego warunku umożliwiającego wykonawcy realizowanie zadania.

Analizując przepisy ustawy o publicznym transporcie zbiorowym dotyczące wykonywania przewozów o charakterze użyteczności publicznej, można dostrzec model dopuszczający możliwość zarówno zawierania umów cywilnoprawnych z podmiotami prywatnymi lub gminnymi osobami prawnymi, jak i powierzania realizowania zadania $\mathrm{w}$ trybie bezumownym gminnym jednostkom organizacyjnym nieposiadającym osobowości prawnej. Relacje między organizatorem a operatorem transportu zbiorowego mogą być ukształtowane zarówno na zasadzie konkurencji operatorów o zamówienia udzielane przez organizatora, jak i na zasadzie powierzenia wykonywania zadania przez podmiot komunalny (spółkę lub zakład budżetowy) z pominięciem procedur konkurencyjnych, w drodze 
aktu władczego lub bezpośredniego zawarcia umowy. Gmina posiada swobodę w wyborze najkorzystniejszego z jej punktu widzenia rozwiązania.

Opisane wyżej modele stanowią przykłady różnorodnych rozwiązań prawnych stosowanych w różnych sektorach gospodarki komunalnej. W zależności od rodzaju zadania, obowiązywać może inna procedura związana z wyborem wykonawcy zadania (np. przetarg, umowa zawarta z własną spółką, powierzenie realizacji zadania gminnej jednostce organizacyjnej w akcie prawnym o charakterze władczym). Rola gminy i relacje pomiędzy gminą a podmiotem realizującym zadanie o charakterze użyteczności publicznej mogą kształtować się w różny sposób. Przedsiębiorstwa mogą pozostawać w ścisłej zależności od gminy, która decyduje o możliwości prowadzenia przez nie działalności oraz kwestiach podstawowych dla jej prowadzenia (np. przedsiębiorstwa wodociągowo-kanalizacyjne). Mogą również zachować większą niezależność od gminy, która nie ogranicza prawa do prowadzenia działalności, ani nie decyduje o ich planach inwestycyjnych, wstępując w stosunki umowne z gminą.

\section{Bibliografia:}

Banasiński C., Kulesza M., Ustawa o gospodarce komunalnej. Komentarz, Dom Wydawniczy ABC, Warszawa 2002.

Borodo A., Samorzqd terytorialny. System prawnofinansowy, LexisNexis, Warszawa 2008.

Gonet W., Uwagi o formach prowadzenia gospodarki komunalnej, „Samorząd Terytorialny” 2008, nr 7-8, s. 65-75.

Izdebski H., Samorzq̨d terytorialny. Podstawy ustroju i działalności, LexisNexis, Warszawa 2009.

Rakoczy B., Zbiorowe zaopatrzenie w wodę i zbiorowe odprowadzanie ścieków w praktyce przedsiębiorstw wodociagowo-kanalizacyjnych, Izba Gospodarcza Wodociągi Polskie, Bydgoszcz 2012.

Szydło M., Ustawa o gospodarce komunalnej. Komentarz, Warszawa 2008.

Wantoch-Rekowski J., Spółki komunalne a Prawo zamówień publicznych [w]: A. Borodo (red.), Aktualne problemy rozwoju gospodarczego gmin i powiatów, Włocławek 2006.

Żyła E., Najlepsze pomysły na komunikację miejskq, „Wspólnota” 2013, nr 5, s. 26-31. 